\title{
PRESENT STATE OF EVALUATING MALNUTRITION IN THE ELDERLY - ANALYSING INDICATORS
}

\author{
Dana Hrnciarikova ${ }^{\text {a*}}$, Bozena Juraskova ${ }^{\mathrm{a}}$, Zdenek Zadak ${ }^{\mathrm{b}}$, Miloslav Hronek ${ }^{\mathrm{c}}$
}

\author{
a Department of Gerontology and Metabolic Care, University Hospital, Hradec Kralove, Faculty of Medicine, Charles \\ University in Hradec Kralove \\ ${ }^{b}$ Centrum for science and research, University Hospital and Faculty of Medicine, Charles University in Hradec Kralove \\ c Faculty of Pharmacy, Charles University in Hradec Kralove \\ e-mail:danahrnciarikova@seznam.cz
}

Received: October 20, 2006; Accepted: November 20, 2006

Key words: Malnutrition/Geriatric patient/Anthropometry/MNA (mini nutrition assessment)

Objectives: Malnutrition in old age is a significant problem. The study presents a survey of the basic methods used in the diagnosis of malnutrition in the elderly such as nutritional anamnesis, anthropometrical, laboratory a functional examinations and indicating specific differences as compared with a younger population.

Methods: We conducted a search of Czech and foreign literature (using PubMed, Medline) focused on diagnostic methods and examinations of nutritional markers especially by geriatric patients published from 1994 to 2006.

Results and conclusions: The examinations we presented are simple, non-invasive methods, which can we use especially for out-patient monitoring of geriatric patients to recognize nutrition disorders. Timely diagnosis of malnutrition in the elderly can prevent patients from worsing self-sufficiency and quality of life of the seniors, increasing the risk of institutionalisation, prolonging hospitalisations due to increased rates of complications and increasing the treatment costs and mortality of geriatric patients.

\section{INTRODUCTION}

Nutrition disorders appear more often in old age than in the young. Nearly all individuals over 80 years of age suffer from a certain degree of malnutrition. This is a specific characteristic of old age, when body compositional changes with a physiological decline in muscle mass and rise in the percentage of fat in the organism appears. This process in combination with pathological conditions typical for old age as polymorbidity, polypragmasia, loss of dentition, bad psychological and socio-economic conditions leads very rapidly to the development of malnutrition ${ }^{4}$. Malnutrition is a complex problem afflicting several organ systems therefore when evaluating the nutritional condition no specific marker can be utilised on its own to unambiguously prove malnutrition and it is necessary to use a combination of different methods (nutrition anamnesis, anthropometrical, laboratory and functional examination). When diagnosing malnutrition in old age, it is necessary to consider the fact that a geriatric patient differs from a young adult and therefore the methods used could have a certain limitations that one should be aware of, i.e. other levels for pathological values etc.

\section{Nutrition anamnesis}

Gathering a nutrition history should be an inseparable part of nutritional screening. We especially look for changes in body weight (see below). It is also important to identify dietary habits, dietary restrictions and diseases of the gastrointestinal tract ${ }^{4}$. Dental condition should not be overlooked in geriatric patients along with the influence of other concurrent diseases, cognitive functions, mobility disorders and last but not least even social factors as loneliness or lack of financial means ${ }^{7,11}$.

Mini nutrition assessment (MNA) is a widely used international questionnaire to evaluate the nutritional state of seniors. This aid can, with high sensitivity (98.9\%), specificity (94.3\%) and diagnosis accuracy (97.2\%) selected the patients with risk of malnutrition. It closely correlates with biochemical (albumin, prealbumin, transferrin levels, and lymphocyte numbers) and anthropometrical markers (measuring of subcuticular fat, arms circumference) that was verified by a number of clinical studies on wide sets of geriatric patients ${ }^{3,8,10}$. Performing the MNA is not time consuming, the complete form does not exceed 15 minutes and a shorten version can be filled in $3 \mathrm{~min}$. Performing a complex MNA is suitable especially in risk groups of institutionalised or hospitalized seniors. MNA itself consists of 4 groups of questions and measurements: basic anthropometrical measurement (BMI, arm, hip circumference, loss of body mass), total condition evaluation (mobility, self-sufficiency, chronic defects, presence of acute disease, psychological condition and polypragmasia), eating habits (questions aimed at food and liquid consumption and the ability to eat) and judging the condition of nutrition and health. A certain number of points are allocated to each question; maximum reached is 29 points, minimum 0 point. Normal MNA and a good condition of nutrition is considered above 24 points, endanger risk of malnutri- 
tion appears in the range 17-23.5 points and score under 17 verifies malnutrition?

\section{Anthropometrical examinations}

Anthropometrical indicators are simple, non-invasive and cheap methods of monitoring the state of nutrition and are especially suitable for out-patient monitoring. These measurements can help to reveal the extent of affliction in given individual. The anthropometrical minimum for purposes of nutritional evaluation is measurement of arm circumference and the skin fold above triceps.

Body mass. Isolated measurement of body mass could be misleading, it is important to follow the values in time. Unwanted loss of body mass of more than $5 \%$ in one month or more than $10 \%$ from the baseline body mass after 6 months could reflect malnutrition. Decrease of more than $10 \%$ in one month or more than $20 \%$ in two months testifies to a serious degree of malnutrition with an increased risk of infectious and postoperative complications, higher postoperative morbidity and mortality ${ }^{1}$. In seniors weighing could be impossible due to inability to stand. In lying patients body mass and height could be estimated by special anthropometrical techniques. Unwanted decrease of body mass in the elderly, apart from malnutrition, could also be caused by even by other diseases (tumours, serious cardiac and respiratory failures, dementia or depression) or social risk conditions (poverty and solitude) $)^{11}$.

Body-mass index (BMI). A basic guide to evaluate the nutritional state and the most commonly used mass-height indicators. Normal values of BMI are found in the range $20-25 \mathrm{~kg} / \mathrm{m}^{2}$. BMI under $18.5 \mathrm{~kg} / \mathrm{m}^{2}$ specifies cachechia, under $16 \mathrm{~kg} / \mathrm{m}^{2}$, but in the seniors the risk is already under $20 \mathrm{~kg} / \mathrm{m}^{2}$ especially due to an increase of postoperative complications.

Mid-arm circumference. Measurement of the arm circumference is a simple method for determination of body mass quantity. It is measured on the non-dominant extremity at a site half way between the acromion and olecranon. Normal values are $29.3 \mathrm{~cm}$ in men and $28.5 \mathrm{~cm}$ in women, for a severe malnutrition with loss of body mass testifies circumference smaller than $19.5 \mathrm{~cm}$ in men and 15.5 in women. It is suitable to combine measurement of arm circumference and skin fold above the triceps ${ }^{11}$.

\section{Measurement of subcutaneous fat}

Skin fold above the triceps. Determination of skin fold above the triceps indicates the quantity of subcutaneous fat. The measurement is carried out on the non-dominant extremity by a special apparatus calliper. The normal value is $12.5 \mathrm{~mm}$ in men and $16.5 \mathrm{~mm}$ in women, values less than $8 \mathrm{~mm}$ in men and $10 \mathrm{~mm}$ in women indicate significant malnutrition ${ }^{11}$. In seniors this measurement may not be precise due to the loss of skin elasticity.

Determination of the circumference of musculature of the arm. It quantifies loss of musculature by calculating means of measurements of arm circumference which is deducted from layer of subcutaneous tissue measured with calliper upon triceps. Normal values are $25.3 \mathrm{~cm}$ in

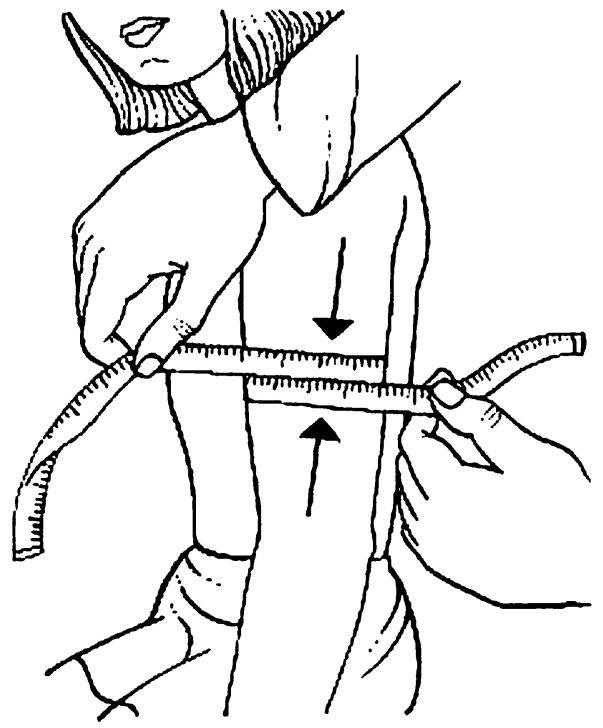

Fig. 1. Measurement of arm circumference (taken from ref. $\left.{ }^{11}\right)$.

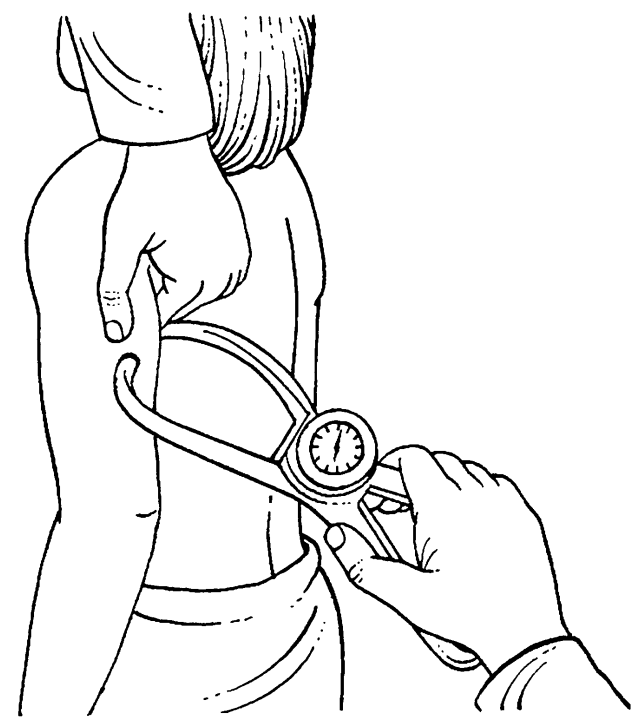

Fig. 2. Measurement of subcutaneous fat (taken from ref. $\left.{ }^{11}\right)$.

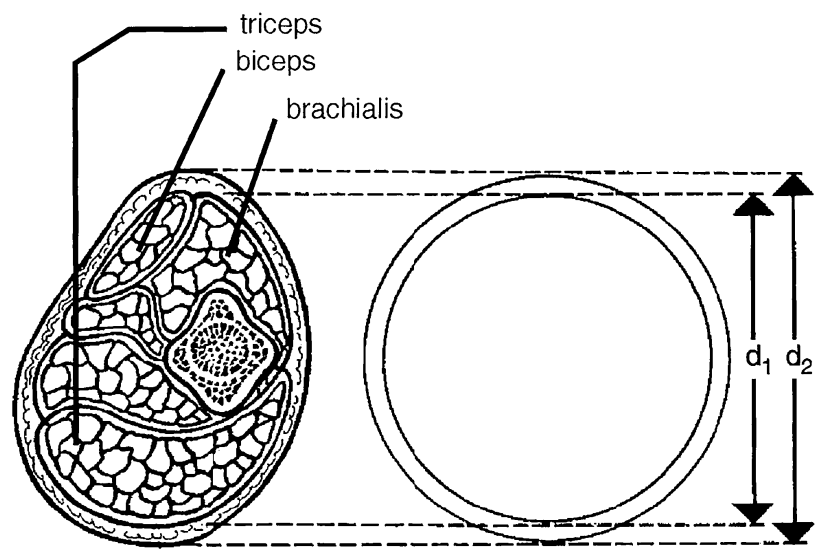

Fig. 3. Measurement of arm musculature circumference (taken from ref. ${ }^{11}$ ). 
Table 1. Mini Nutritional Assessment (taken from ref. ${ }^{2}$ ).

\section{MINI NUTRITIONAL ASSESSNENT (MNA)}

I. ATHROPOMETRIC ASSESSMENT

1. Body Mass Index (BMI) (weight in $\mathrm{kg}$ ) / (height in $\mathrm{m})^{2}$
a. $\mathrm{BMI}<19$
b. BMI 19 to $<21$
c. BMI 21 to $<23$
d. $\mathrm{BMI} \geq 23$

$$
\begin{aligned}
& =0 \text { points } \\
& =1 \text { point } \\
& =2 \text { points } \\
& =3 \text { points }
\end{aligned}
$$

2. Mid-arm circumference (MAC) in $\mathrm{cm}$
a. $\mathrm{MAC}<21$
b. MAC $21 \leq 22$
c. $\mathrm{MAC}>22$

$=0.0$ points

$=0.5$ points

$=1.0$ points

3. Calf circumference $(\mathrm{CC})$ in $\mathrm{cm}$
a. $\mathrm{CC}<31$
$=0$ points
b. $\mathrm{CC} \geq 31$
$=1$ point

4. Weight loss during last 3 months
a. weight loss greater than $3 \mathrm{~kg}$
b. does not know
c. weight loss between 1 and $3 \mathrm{~kg}$
d. no weight loss
$=0$ points
$=1$ point
$=2$ points
$=3$ points

II. GENERAL ASSESSMENT

5. Lives independently (not in nursing home or hospital)
a. no
$=0$ points
b. yes
$=1$ point

6. Takes more than 3 prescription drugs per day
a. yes
$=0$ points
b. no
$=1$ point

7. Has suffred psychological stress or acute disease in the past 3 months
a. yes
$=0$ points
b. no
$=2$ points

8. Mobility
a. bed or chair bound
$=0$ points
b. able to get out of bed/chair but does not go out
c. goes out
$=1$ point

9. Neuropsychological problems
a. severe dementia or depression
$=0$ points
b. mild dementia
$=1$ point
c. no psychological problems
$=2$ points

10. Pressure sores or skin ulcers
a. yes
$=0$ points
b. no
$=1$ point

\section{DIETARY ASSESSMENT}

11. How many full meals does the patient eat daily?
a. 1 meal
$=0$ points
b. 2 meals
$=1$ point
c. 3 meals
$=2$ points

12. Selected comsumption markers for protein intake

* at least 1 serving of dairy products per day? yes/no

* 2 or more servings of legumes or eggs per week?

* meat, fish or poultry every day? yes/no
a. if 0 or 1 yes
$=0.0$ points
b. if 2 yes
$=0.5$ points
c. if 3 yes
$=1.0$ points

13. Consumes two or more servings of fruits or vegetables per day?
a. no
$=0$ points
b. yes
$=1$ point

14. Has food intake declined over the past three months due to loss of appetite, digestive problems, chewing or swallowing difficulties?
a. severe loss of appetite
b. moderate loss of appetite
$=0$ points
c. no loss of appetite
$=1$ point
$=2$ points

15. How much fluid is consumed per day?
a. less than 3 cups
$=0.0$ points
b. 3 to 5 cups
$=0.5$ points
c. more than 5 cups
$=1.0$ points
16. Mode of feeding
a. unable to eat without assistance
$=0$ points
b. self-fed with some difficulty
$=1$ point
c. self-fed without any problem
$=2$ points

IV. SELF ASSESSMENT

17. Do they view themselves as having nutritional problems?
a. major malnutrition
$=0$ points
b. does not know or moderate malnutrition
c. no nutritional problem
$=1$ point
$=2$ points

18. In comparison with other people of the same age, how do they consider their health status?
a. not as good
$=0.0$ points
b. does not know
$=0.5$ points
c. as good
$=1.0$ points
d. better
$=2.0$ points

ASSESSMENT TOTAL (max. 30 points)

\section{MALNUTRITION INDICATOR SCORE}

$\geq 24$ points well-nourished

17 to 23.5 points at risk of malnutrition $<17$ points malnourished 
Table 2. Values of anthropometrical examinations.

\begin{tabular}{|l|c|c|c|}
\hline \multicolumn{2}{|c|}{ anthropometrical examinations } & men & women \\
\hline \multirow{2}{*}{ Mid-arm circumference (cm) } & normal & $29.3 \mathrm{~cm}$ & $28.5 \mathrm{~cm}$ \\
\cline { 2 - 4 } & severe malnutrition & $<19.5 \mathrm{~cm}$ & $<15.5 \mathrm{~cm}$ \\
\hline \multirow{2}{*}{ Skin fold above the triceps (mm) } & normal & $12.5 \mathrm{~mm}$ & $16.5 \mathrm{~mm}$ \\
\cline { 2 - 4 } & severe malnutrition & $<8 \mathrm{~mm}$ & $<10 \mathrm{~mm}$ \\
\hline \multirow{2}{*}{ Circumference of musculature of the arm $(\mathrm{cm})$} & normal & $25.3 \mathrm{~cm}$ & $23.2 \mathrm{~cm}$ \\
\cline { 2 - 4 } & severe malnutrition & $<15.2 \mathrm{~cm}$ & $<13.9 \mathrm{~cm}$ \\
\hline
\end{tabular}

men and $23.2 \mathrm{~cm}$ in women, values $15.2 \mathrm{~cm}$ in men and $13.9 \mathrm{~cm}$ in women testifies for severe malnutrition ${ }^{11}$.

\section{Laboratory examinations}

Amongst laboratory findings current practise most often includes biochemical examination, where specifically a decrease in serum proteins identifies malnutrition.

Biochemical examinations. Biochemical markers belong among the basic examination in the diagnosis of malnutrition. Formation of serum proteins in the liver is connected with the nutritional state of the organism, in malnutrition proteosynthetic liver function is usually decreased. According to half-life of individual plasma proteins the duration of malnutrition can be determined.

Levels of serum proteins decrease also during an inflammatory reaction (negative proteins of acute phase) by transfer of plasma proteins into reactants of acute phase $C$ reactive protein (CRP), therefore it is suitable to determine simultaneously even CRP, whose value increases during inflammation (positive protein of acute phase) and measured values compare mutually.

Transferrin level is necessary to evaluate in dependence on serum level of iron. Low values of serum proteins in the elderly can be simulated by dehydration, after re-hydration a decrease in the markers occurs due to hemodilution. Beside the values of plasma proteins even low value of total cholesterol (less than $3.0 \mathrm{mmol} / \mathrm{l}$ ) and hormones of thyroid gland could testify for malnutrition, lower value of creatinine can demonstrate low capacity of musculature mass. These indicators must be evaluated with respect to intercurrently on-going diseases 5 .

Total protein (TP). TP has a long biological half-life, therefore it is a rather late indicator of protein malnutrition. Low TP levels indicate a long standing protein deficit. TP decrease under $55 \mathrm{~g} / 1$ is considered to be serious. TO value could be influenced especially with liver or kidney disorders, by degree of dehydration or a concurrent inflammatory process.

Albumin. Determining the level of albumin was so far considered to be a golden standard in the evaluation of nutritional condition. It remains to be a suitable marker for screening and monitoring of malnutrition, its indicative value is increased in combination with prealbumin, transferrin or cholinesterase. Decrease of albumin serum level correlates with total prognosis of patients, it is an independent indicator of severity of clinical state ${ }^{11}$.

Albumin has relatively long half-life 20-21 days. The values giving evidence for significant malnutrition in seniors are under $23 \mathrm{~g} / \mathrm{l}$. The state of hydration, transit among intravascular and extravascular space, liver and kidney disease could influence albumin concentration. It is also a negative protein of acute phase and it is suitable to relate its values to CRP levels 6 .

Prealbumin. Prealbumin has the shortest biological half-life 1-2 days, it is the reason why it is most suitable for evaluation of acute protein malnutrition. Values under $0.10 \mathrm{~g} / \mathrm{l}$ testify for serious malnutrition. It is a beneficial marker for monitoring the nutritional condition. However, concurrently it belongs amongst the negative proteins of acute phase and it is necessary to evaluate it in relation with CRP. Lower levels could appear in conditions that impair hepatic function ${ }^{6}$.

Transferrin. Half-life of transferrin is 5-7 days, it is an early indicator of protein malnutrition, but is less specific. Serum concentration testifying for malnutrition is under $1.5 \mathrm{~g} / 1$, but it can be significantly influenced by the amount of iron in the organism, acute inflammation disease (negative protein of acute phase) or chronic hepatopathy ${ }^{6}$.

Cholinesterase. Half-life of cholinesterase is also 57 days; its level correlates well with albumin level, but is significantly dependent on liver function and some drugs (fysostigmin, cyclophosphamide etc.) It is a suitable marker for monitoring nutritional state ${ }^{6}$.

\section{Haematological and immunological examinations}

Determination of absolute number of lymphocytes belongs to haematological and immunological examinations; even anaemia could indicate malnutrition (from lack of iron, folic acid or vitamin B 12). Anergine reaction to immunological intradermal skin tests often appears in old age.

Absolute lymphocytes number. Malnutrition leads to the deteriorated function of the immune system at first on the cellular level and subsequently even affecting humoral immunity. We evaluate absolute lymphocytes count, its normal value should not drop below $1500 / \mu 1\left(\mathrm{ref}^{7}\right)$, below this limit the risk of malnutrition increases and decline below $900 / \mu 1$ demonstrates significant immunity affliction 
with a high risk of severe malnutrition. It is necessary to exclude in advance other aetiology of a decrease in lymphocytes (hematooncological disease, TBC, viruses, etc.).

\section{Functional examination}

Dynamometry. Judgement of function condition of muscle tissue is necessary for judging of seriousness of clinical state. For outpatient monitoring is suitable hand dynamometer, which measures the strength of muscle grip (hand grip). In case of nutrition disorder muscle strength is usually decreased. Muscle strength decreases physiologically in old age, but in malnourished seniors the decrease is more significant. Disadvantage of dynamometry is, that especially in old age it could be considerably influenced by the non-cooperation of the patient or his disability to grip the dynamometer due to rheumatic diseases of hand joints ${ }^{7}$.

\section{CONCLUSION}

The occurrence of nutrition disorders amongst geriatric patients is very frequent. Malnutrition worsens self-sufficiency of the seniors, increasing risk of institutionalization, prolonged hospitalization due to higher rate of complications, increases costs of treatment and also mortality of gerontological patients. Malnutrition diagnosis must be complex and it is a combination of nutrition anamnesis, anthropometrical, laboratory a function examinations with different statement value. Followed markers in old age could have certain differences from younger population.

\section{ACKNOWLEDGEMENTS}

This work was supported by grant No NR/8159-3 of IGA, Ministry of Health, Czech Republic.

\section{REFERENCES}

1. Beneš P. Základy umělé výživy. Nutriční péče pro nemocniční praxi. Praha: Maxdorf; 1999.

2. Guigoz Y, Vellas B, Garry PJ. Mini Nutritional Assessment: A practical assessment tool for grading the nutritional state of elderly patients. In: Vellas B, Guigoz Y, Garry PJ et al. The Mini Nutritional Assessment: MNA. Nutrition in the Elderly. Facts and Research in Gerontology. Supplement 2. New York: Springe Publishing Co; 1994. p. 15-59.

3. Kagansky N, Berner Y, Koren-Morag N, Perelman L, Knobler H, Levy S. Poor nutritional habits are predictors of poor outcome in very old hospitalized patiens. Am J Clin Nutr 2005; 82(4):784791.

4. Kalvach Z, Zadák Z, Jirák R, Zavázalová H, Sucharda P. Geriatrie a gerontologie. Praha: Grada Publishing; 2004

5. Kohout P. Dokumentace a hodnocení nutričního stavu pacientů. Praha: Maxdorf; 2004

6. Kohout P. Výživa u pacientů s idiopatickými střevními závody. Praha: Maxdorf; 2004

7. Navrátilová M, Češková E, Sobotka L. Klinická výživa v psychiatrii. Praha: Maxdorf; 2000.

8. Ruiz-Lopez MD, Artacho R, Oliva P, Moreno-Torres R, Bolanos J, de Teresa $\mathrm{C}$ et al. Nutritional risk in institutionalized older women determined by the Mini Nutritional Assessment test. What are the main factors? Nutr 2003; 19(9):767-71.

9. Topinková E. Využití standardizovaných škál pro hodnocení stavu výživy u starších nemocných. Čes ger rev 2003; 1(1):6-11.

10. Vellas B, Guigoz Y, Baumgartner M, Garry PJ, Lauque S, Albarede JL. Relationships between nutritional markers and the mini-nutritional assessement in older persons. J Am Geriatr Soc 2000; 48(10):1300-9.

11. Zadák Z. Výživa v intenzivní péči. Praha: Grada Publishing; 2002. 